\title{
Efek pemberian ekstrak klorofil daun pepaya (carica papaya, linn.) terhadap kadar ast dan alt serum
}

\author{
Kusmadewi Eka Damayanti', Noor Wijayahadi², Niken Puruhita²
}

\begin{abstract}
Background: Pharmacological therapy is one of the therapy modalities which carries the hepatic injury as one of its side effects. Nowadays, curcuma tablets has become choice of hepatoprotector. Other substance which has the possibilities of hepatoprotection activities is chlorophyll. The study is aimed to investigate the effect of papaya leaves chlorophyll extracts towards the serum AST and serum ALT levels on high-dose-paracetamol-induced Wistar rats.

Materials and methods: This was an experimental study applying pretest-posttest controlled group design. Twenty eight Wistar rats 8-12 weeks age and weighted 185-220 grams assigned into four groups, namely group I (control), group II (paracetamol $750 \mathrm{mg} / \mathrm{kg} \mathrm{bw}+$ no hepatoprotector agent), group III (paracetamol $750 \mathrm{mg} / \mathrm{kg} \mathrm{bw}+$ curcuma $100 \mathrm{mg} / \mathrm{kg} \mathrm{bw),} \mathrm{and} \mathrm{group} \mathrm{IV}$ (paracetamol $750 \mathrm{mg} / \mathrm{kg} \mathrm{bw}+$ papaya leaves chlorophyll extracts $300 \mathrm{mg} / \mathrm{kg} \mathrm{bw}$ ). The hepatoprotector agents were administered for a week, while the high dose paracetamol was administered for three consecutive days (day 5, 6, and 7). The pretest samples were drawn on the fifth day before the administration of high dose paracetamol, and the posttest samples were drawn on eightth day.

Results: There were no difference among four groups on serum AST and serum ALT levels before the administration of high dose paracetamol, $p=0.522$ dan $p=0.682$, respectively. After the administration of high dose paracetamol, there were differences among four groups on both variables, both $p=0.000$. The post-hoc test showed that differences happened on all four groups $(p<0.05)$.
\end{abstract}

Conclusion: Chlorophyll extract of papaya leaves can inhibit liver injury on high-dose-paracetamol-induced-Wistar rats.

Keywords: Hepatoprotection; chlorophyll extracts; papaya leaves; serum AST; serum ALT

\begin{abstract}
ABSTRAK
Latar belakang: Penggunaan obat merupakan salah satu modalitas terapi yang salah satu efek sampingnya adalah kerusakan hepar. Dewasa ini, tablet kurkuma diberikan sebagai usaha pencegahan kerusakan hepar akibat obat-obatan. Zat lain yang sangat dimungkinkan memiliki aktivitas hepatoproteksi adalah klorofil. Studi ini bertujuan untuk membuktikan efek pemberian ekstrak klorofil daun pepaya terhadap kadar AST dan ALT serum tikus Wistar yang diinduksi paracetamol dosis tinggi.

Metodologi penelitian: Studi ini merupakan studi eksperimental dengan rancangan pretest-posttest controlled group. Dua puluh delapan hewan coba tikus putih (Rattus norvegicus strain Wistar) berusia 8-12 minggu dengan berat badan antara 185-220

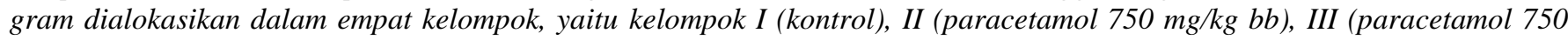

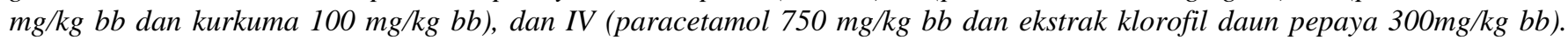
Perlakuan proteksi hepar dengan kurkuma, ekstrak klorofil daun pepaya maupun placebo (minyak jagung) dilakukan selama 7 hari, sedangkan perlakuan perusakan hepar dengan paracetamol atau placebo (normal saline) dilakukan selama 3 hari, yaitu pada hari ke-5,6, dan ke-7. Pengambilan darah untuk pemeriksaan AST dan ALT serum dilakukan pada hari ke-5 (sebelum pemberian paracetamol atau placebo) dan hari ke-8.

Hasil penelitian: Tidak didapatkan perbedaan bermakna antara keempat kelompok pada kadar AST dan kadar ALT serum sebelum perlakuan perusakan hepar, $p=0.522$ dan $p=0.682$, secara berurutan. Setelah perlakuan perusakan hepar, didapatkan perbedaan bermakna antara keempat kelompok pada kadar AST dan kadar ALT serum, p=0.000 pada kedua variabel. Uji posthoc menunjukkan bahwa perbedaan terjadi pada setiap kelompok terhadap kelompok lainnya $(p<0.05)$.

Simpulan: Pemberian ekstrak klorofil daun pepaya dapat mencegah kerusakan hepar tikus Wistar yang diinduksi paracetamol dosis tinggi.
\end{abstract}

Kata kunci: Hepatoproteksi; klorofil; daun pepaya; AST serum; ALT serum

\section{PENDAHULUAN}

Penggunaan obat-obatan merupakan salah satu modalitas terapi yang digunakan secara luas dalam praktek kedokteran. Meskipun demikian, penggunaan obat-obatan bukan tanpa risiko efek samping.Salah satu efek samping obat yang sering ditemui adalah

\footnotetext{
1. Jurusan Gizi Fakultas Kedokteran UNS

2. Fakultas Kedokteran Universitas Diponegoro
}

terjadinya hepatotoksisitas, karena hepar merupakan organ utama yang berperan dalam proses metabolisme obat. Obat-obatan yang sering menyebabkan hepatotoksisitas antara lain obat-obatan yang zat aktif atau metabolitnya berefek langsung terhadap sel hepar sehingga sel mengalami disfungsi.Pemeriksaan AST dan ALT serum dilakukan secara periodik, khususnya pada pasien dalam terapi farmakologis yang berpotensi merusak hepar atau penggunaan obat-obatan yang bersifat hepatotoksik ${ }^{1,2}$. 
Kejadian DILI (Drug-Induced Liver Injury) merupakan salah satu efek samping terapi farmakologis. Di negara barat, kejadian DILI secara umum hanya sebesar 1-2 kasus per 100.000 orang tahun, namun di Jerman diketahui bahwa $40 \%$ dari seluruh kasus gagal hepar akut merupakan kasus $D I L I^{3}$. Suatu studi menunjukkan bahwa terjadi 6.5 episode morbiditas akibat obat di setiap 100 rumah sakit. Beberapa studi juga menunjukkan bahwa banyak kasus rawat inap yang merupakan akibat dari efek samping obat $^{4}$.

Berbagai penelitian dilakukan untuk memperoleh jalan keluar sehingga kejadian hepatotoksisitas obat dapat diminimalkan, misalnya melalui penelitian dengan menggunakan hewan coba yang menggunakan substansi penginduksi jejas hepar berupa karbon tetraklorida ${ }^{5}$, parasetamol dosis tinggi ${ }^{6,7}$, halotan, amodiaquin, atau lipopolisakarida ${ }^{8}$. Induksi hepatotoksisitas dengan paracetamol dosis tinggi merupakan metode yang paling sering digunakan karena mekanisme kerusakannya telah diketahui, bahannya mudah diperoleh, dan pada dosis tertentu mampu menghasilkan kerusakan hepar yang cukup dengan risiko mortalitas hewan coba yang minimal ${ }^{9,10}$.

Dalam hal pencegahan atau pengobatan hepatotoksisitas yang diakibatkan obat, kurkuma merupakan salah satu zat yang memiliki peran penting ${ }^{11,12}$. Kurkuma memiliki banyak aktivitas biologis yang salah satunya sebagai agen anti-oksidan. Penggunaan kurkuma sebagai anti-oksidan terbukti dapat mengoptimalkan ekspresi gen enzim-enzim antioksidan misalnya superoksid dismutase, glutathion peroxidase, dan katalase. Melalui optimalisasi enzimenzim antioksidan tersebut produksi spesies oksigen reaktif (Reactive Oxygen Species, ROS) di hepar dapat ditekan sehingga kerusakan oksidatif sel-sel hepar dapat dicegah. Hal tersebut juga berlaku pada pencegahan kerusakan hepar akibat metabolit obat ${ }^{12}$.

Zat lain yang juga diduga memiliki aktivitas anti-oksidan tinggi adalah klorofil. Klorofil banyak dijual bebas dan diklaim memiliki berbagai khasiat meskipun belum cukup didukung dengan studi ilmiah. Belum ada penelitian yang secara khusus menunjukkan bukti ilmiah atas efektivitas klorofil sebagai hepatoprotektor, meskipun beberapa tulisan menjelaskan kemampuan klorofil sebagai hepatoprotektor berdasarkan fungsinya di hepar. Berdasarkan hal tersebut di atas, peneliti bermaksud membuktikan efek ekstrak klorofil daun pepaya terhadap kadar AST dan ALT serum tikus putih strain Wistar yang diinduksi parasetamol dosis tinggi.

\section{BAHAN DAN METODE}

Penelitian ini merupakan penelitian eksperimental dengan rancangan pretest-posttest controlled group. Hewan coba yang digunakan dalam penelitian ini adalah tikus putih (Rattus norvegicus) strain Wistar berusia 8-12 minggu dengan kisaran berat badan 185-220 gram yang diperoleh dari Unit Pemeliharaan Hewan Percobaan (UPHP) Universitas Gadjah Mada Yogyakarta. Sebelum masa perlakuan, hewan coba diaklimatisasi dalam lingkungan laboratorium selama tujuh hari. Selama masa aklimatisasi, ekstrak klorofil disiapkan dengan teknik maserasi dalam ruang gelap menurut cara Dikio dan Isabirye ${ }^{13}$ dengan menggunakan pelarut aseton. Setelah diperoleh ekstrak klorofil, aseton diuapkan dalam evaporator. Ekstrak klorofil kemudian dilarutkan dalam $2 \mathrm{ml}$ minyak jagung sebelum diberikan kepada hewan coba.

Dua puluh delapan ekor tikus putih dialokasikan secara acak ke dalam empat kelompok, yaitu Kelompok I (kontrol), II (mendapatkan Parasetamol $750 \mathrm{mg} / \mathrm{kg}$ bb saja), III (mendapatkan Parasetamol 750 $\mathrm{mg} / \mathrm{kg}$ bb dan kurkuma $100 \mathrm{mg} / \mathrm{kg} \mathrm{bb}$ ), dan IV (mendapatkan Parasetamol $750 \mathrm{mg} / \mathrm{kg}$ bb dan ekstrak klorofil daun pepaya $300 \mathrm{mg} / \mathrm{kg} \mathrm{bb}$ ). Pada hari ke-0 sampai hari ke-5, hewan coba mendapatkan agen hepatoprotektor berupa kurkuma, ekstrak klorofil daun pepaya, atau minyak jagung sebagai placebo. Pada hari ke-5, sampel darah diambil dari vena retroorbitalis sebagai sampel darah pra-perlakuan (pretest). Setelah sampel darah diambil, pada hari ke-5, 6, dan ke-7 hewan coba mendapatkan agen hepatoprotektor dan parasetamol dosis tinggi dengan selang waktu pemberian 30 menit. Pada hari ke-8, sampel darah diambil melalui vena retroorbitalis sebagai sampel darah pasca-perlakuan (posttest). Pemeriksaan kadar AST dan ALT serum dilakukan dengan metode spektrofotometri.

Data kadar AST dan ALT sebelum dan sesudah perlakuan perusakan hepar (hari ke-5 dan hari ke-8, secara berurutan) diuji normalitasnya menggunakan uji Shapiro-Wilk, karena besar sampel kurang dari 50 dan skala data rasio. Uji Shapiro-Wilk menunjukkan nilai $\mathrm{p}$ $>0,05$ pada kedua variabel, sehingga dapat disimpulkan bahwa variabel kadar AST dan ALT terdistribusi normal. Berdasarkan hasil uji normalitas data di atas, maka uji yang digunakan untuk menguji perbedaan keempat kelompok pada sebelum dan sesudah perlakuan adalah uji ANOVA. Pada hasil uji dengan perbedaan yang signifikan secara statistik $(\mathrm{p}<$ $0,05)$ dilanjutkan dengan uji post-hoc LSD. 


\section{HASIL}

Hasil analisis data kadar AST dan ALT serum sebelum perlakuan menunjukkan bahwa tidak ada perbedaan yang bermakna antara keempat kelompok ( $\mathrm{F}=0,768, \mathrm{p}=0,522$ dan $\mathrm{F}=0,505, \mathrm{p}=0,682$, berurutan). Hal ini menunjukkan bahwa keempat kelompok memiliki kadar AST dan ALT serum yang sama sebelum perlakuan.

Hasil analisis data kadar AST dan ALT serum setelah perlakuan menunjukkan bahwa terdapat perbedaan yang bermakna antara keempat kelompok $\left(\mathrm{F}=5,991 \times 10^{3}, \mathrm{p}=0,000\right.$ dan $\mathrm{F}=6,982 \times 10^{3}, \mathrm{p}=0,000$, berurutan). Hal ini menunjukkan bahwa keempat kelompok memiliki kadar AST dan ALT serum yang berbeda setelah perlakuan perusakan hepar dengan parasetamol dosis tinggi. Perbedaan ini kemudian diteliti lebih lanjut dengan uji post-hoc LSD. Uji posthoc menunjukkan bahwa terdapat perbedaan bermakna pada semua kelompok.

\section{PEMBAHASAN}

Penelitian ini menemukan bahwa klorofil memiliki efek terhadap kadar AST dan ALT serum pada tikus putih yang diinduksi parasetamol dosis tinggi. Efek klorofil dalam hal ini mampu memberikan efek berupa kadar AST dan ALT yang rendah. Hal ini menunjukkan bahwa klorofil mampu mencegah kerusakan hepar lebih baik dibandingkan kurkuma. Hasil di atas sejalan dengan penelitian Saputri dkkyang secara histopatologis menunjukkan bahwa pemberian klorofil mampu mencegah kerusakan sel hepar dengan lebih baik dibandingkan kurkuma ${ }^{14}$.

Mekanisme klorofil dalam hepatoproteksi sampai saat ini belum diketahui secara pasti. Selama ini klorofil dipercayai memiliki aktivitas antioksidan dan mampu melindungi sel-sel tubuh dari pengaruh buruk ROS. Hal ini didukung dengan pemahaman bahwa tetrapirol (termasuk klorofil) mampu membentuk suatu kelompok metaloenzim prostetik seperti sulfite reduktase, katalase, peroxidase, dan nitrit reduktase yang mampu melakukan berbagai reaksi oksidasi dan reduksi di dalam tubuh. Mekanisme klorofil sebagai antioksidan dan kemampuannya dalam membentuk metaloenzim prostetik inilah yang dimungkinkan berperan dalam pencegahan kerusakan hepar oleh metabolit parasetamol ${ }^{15}$.

Proses kerusakan sel hepar oleh zat asing (obat, metabolisme xenobiotik) diperantarai oleh sitokrom P450 yang berperan sangat penting dalam metabolisme fase 1 yang utamanya merupakan suatu reaksi oksidasi. Pada metabolisme parasetamol, reaksi utama yang berperan adalah reaksi konjugasi yang menyebabkan sebagian besar metabolit parasetamol menjadi lebih polar dan mudah diekskresikan bersama urin, sementara sebagian kecil metabolit parasetamol dimetabolisme oleh sitokrom P450 2E1 untuk kemudian berikatan dengan glutathione untuk diekskresikan melalui ginjal. Pada keadaan intoksikasi parasetamol, jumlah yang harus dimetabolisme oleh sitokrom P450 2E1 ini menjadi sangat besar dan akibatnya jumlah glutathione intraseluler menjadi tidak seimbang dengan metabolit yang harus diikat. Hal ini menyebabkan metabolit reaktif dari parasetamol, Nacetyl benzoquinone-imide atau NAPQI, banyak beredar di dalam sel hepar dan merusak sel hepar. Tingginya NAPQI yang tidak seimbang dengan jumlah glutathione inilah yang menyebabkan kerusakan sel hepar, karena glutathione juga bersifat hepatoprotektan intraseluler ${ }^{16}$.

\section{SIMPULAN}

Mekanisme klorofil sebagai antioksidan dan kemampuannya dalam membentuk metaloenzim prostetik, khususnya glutathione, sangat dimungkinkan berperan dalam pencegahan kerusakan hepar oleh metabolit parasetamol. Seperti dijelaskan di atas bahwa proses metabolisme parasetamol melibatkan peran glutathione dalam mengikat metabolit reaktif parasetamol, sehingga adanya metaloenzim prostetik akan membantu sel hepar dalam mengeliminasi metabolit parasetamol dan meminimalkan kerusakan sel hepar.

Keterbatasan dalam penelitian ini salah satunya adalah tidak ada gradasi dosis ekstrak klorofil daun pepaya yang dibandingkan, sehingga tidak dapat menunjukkan dosis optimal untuk pencegahan kerusakan hepar. Selanjutnya diharapkan dapat menginspirasi penelitian lanjutan untuk mengidentifikasi dosis optimal ekstrak klorofil dari daun pepaya.

\section{DAFTAR PUSTAKA}

1. Sturgill MG dan Lambert GH. Xenobioticinduced hepatotoxicity: mechanism of liver injury and methods of monitoring hepatic function. Clinical Chemistry 1997;43:8(B):1512-1526.

2. Bissel DM, Gores GJ, Laskin DL, dan Hoofnagle JH. Drug-Induced Liver Injury: mechanism and test system. Hepatology Apr 2001;33(4):1009-13.

3. Altinbas A, Bechman LP, Akkiz H, Gerken G, dan Canbay A. Acute Liver Failure. In Mauss, Berg, Rockstroh, Sarrazin, dan Wedemeyer. Hepatology 2014: A Clinical Textbook 5th edition. Germany: Druckhaus-Sued. 2014

4. Morris CJ, Cantrill JA, Hepler CD, dan Noyce PR Preventing drug-related morbidity - determining valid indicators. International Journal for Quality Health Care 2002;14(3):183-198. 
5. Young TH, Tang HS, Chao YC, Lee HS, Hsiong $\mathrm{CH}$, Pao LH, dan Hu OYP. Quantitative rat liver function test by galactose single point method. Laboratory Animals 2008;42:495-504.

6. Ishida $\mathrm{Y}$, Kondo $\mathrm{T}$, Tsuneyama $\mathrm{K}$, Lu $\mathrm{P}$, Takayashu T, dan Mukaida N. The pathogenic roles of tumor necrosis factor p55 in acetaminophen-induced liver injury in mice. Journal of Leukocyte Biology 2004;75:59-67.

7. Zhu JH, McClung JP, Zhang X, Aregullin M, Chen C, Gonzalez FJ, Kim TW, dan Lei XG. Comparative impacts of knock-outs of two antioxidant enzymes on acetaminophen-induced hepatotoxicity in mice. Experimental Biology and Medicine 2009;234:1477-1483.

8. Uetrecht J. Role of animal models in the study of drug-induced hypersensitivity reactions. The AAPS Journal 2006;7(4):E914-E921.

9. Placke ME, Ginsberg GL, Wyand DS, dan Cohen SD. Ultrastructural changes during acute acetaminophen-induced hepatotoxicity in mouse: a time and dose study. Toxicological Pathology 1987;15(4):431-438

10. Katyare dan Satav. Impaired mitochondrial oxidative energy metabolism following paracetamol-induced hepatotoxicity in the rat. $\mathrm{Br}$ J Pharmacol 1989;96:51-58.

11. Kumar GVS. An emphasis on global use of traditional medicinal system and herbal hepatoprotective drugs. Journal of Pharmacologic Research 2014;8(1):28-37.

12. Somchit MN, Sulaiman MR, Noratunlina R, dan Ahmad Z. Hepatoprotective effect of Curcuma longa rhizome in paracetamol-induced liver damage in rats. Proceeding of the Regional Symposium on Environment and Natural Resources. Kuala Lumpur, 10-1 $1^{\text {th }}$ Apr 2002. Vol.1:698-702.

13. Dikio ED dan Isabirye DA. Isolation of Chlorophyll a from spinach leaves. Bulletin of Chemical Society of Ethiopia 2008;22(2):301304.

14. Saputri D, Suyatmi, dan Damayanti KE. Pengaruh ekstrak klorofil daun pepaya (Carica papaya, Linn.) terhadap struktur histologis hepar tikus putih yang diinduksi parasetamol dosis tinggi. Skripsi. Universitas Sebelas Maret Surakarta. 2014

15. Smith AG dan Witty M. Laboratory methods for the study of tetrapyrrols. Dalam Smith AG dan Witty M (eds). Heme, chlorophyll, and billins: methods and protocols. New Jersey: Humana Press. 2002.

16. Maddrey WC. Drug Induced Hepatotoxicity 2005. Journal of Gastroenterology 2005;39(Supp 2):S85-S89. 